\title{
LEGISLATION ON THE PUBLIC PRIVATE PARTNERSHIP AS A FACTOR IN REGIONAL DEVELOPMENT
}

\author{
G. Velkovska* \\ Department of Regional Development, Faculty of Economics, Trakia University, Stara Zagora, Bulgaria
}

\begin{abstract}
Highlights of the legislative basis:

a/ Law on Public Private Partnership;

b/ Regulations for implementing the Law on Public Private Partnership.

$\checkmark$ Public-private partnership (PPP) is a long-term contractual cooperation between one or more public partners on the one hand and one or more private partners, on the other hand, to carry out activities of public interest in achieving better value public input resources and allocation of risks between the partners. $\checkmark$ PPP risks are shared between public and private partner. The distribution of risk is determined on a case of PPPs, depending on the capabilities of partners to evaluate, monitor and manage risks.

$\checkmark$ Public-private partnership is implemented through PPP contract.

The term PPP contract can be from 5 to 35 years

The exact length of the PPP contract is determined based on: financial and economic performance of the PPP project, including the time required of the private partner for recovery of money at the specified rate of return for the private partner; technical and / or technological features of the site, which operates in the public interest and / or of the activity of public interest.

$\checkmark$ Public partners are: ministers and heads of departments - State PPP, which have the object of public interest activities carried out with objects of art. 4 para. 1 from Law for Public - private partnership that are State property and/or which on power of normative act are

assigned of body of central executive power; Mayors of municipalities - for Municipal PPP have for subject activities from public interest carried out with Objects art. 4 para. 1 from Law for Public private partnership that are property of relevant community and/or which by virtue of a normative act are assigned of bodies of local self-government or of Mayors of municipalities;

state and Municipal publicorganizations - for activities from public interest carried out with Objects art. 4 para. 1 from Law for Public - private parntyorstvo that aretheir property and/or which are them provided with Law, act for their creation or with another act of competent authority.

$\checkmark$ Private partner - Party PPP contract can be a capital company has an existing or newly established, subject to the requirements of this law.

Not allowed equity company - party PPP contract to issue bearer shares.

The annual financial statements of the private partner is subject to inspection by a registered auditor under the Independent Financial Audit.

The subject of this material are some basic legal principles characterizing the role of public-private partnership as a factor in regional development.

PPP can be described not only as a factor but also as an important and effective mechanism in the regional development.This mechanism can find a broad scope for application, as both the European and already some examples from the Bulgarian practice show.
\end{abstract}

Key words: Public-private partnership contract for public-private partnership, services of public interest, Council of Ministers, Municipal Council, Municipal Project for Public-Private Partnership , Public Register, Municipal Public-Private Partnerships

\section{INTRODUCTION}

The Public Private Partnership in the modern sense originated in 1992 in Britain, where the so called Private Finance Initiative (PFI) was established for the provision of public services at higher standards, but at an affordable price. The idea was that it would be better if the state was not both the owner and operator of its assets and that the public and private sectors need to focus on what they do best. The traditional method for the state institutions to buy and operate assets came under suspicion because it became obvious 
that they did not have the expertise and resources to do so effectively. The state should focus on determining policies and priorities and making decisions on which public services are needed ${ }^{1}$ According to the cited source for the period 1992-2006 in the UK were implemented 700 projects under the Private Finance Initiative, the value of investments being $£ 46$ billion. This is equivalent to $10-15 \%$ of the capital investment in the UK per year. The government budget for 2007 provided another $£ 11$ billion for implementing public private partnerships by the local authorities. The main focus of local authorities is on social activities and the management of social infrastructure (schools, hospitals, centers for culture and leisure), waste management activities, the security of the population services (fire-fighting activities, the police, prisons), roads and bridges, street lighting.

The public private partnership in this country also finds its manifestations and its lasting effects through the implementation of projects in this area. The legal framework of Public Private Partnership covers mainly two laws - the Law on Public Private Partnership, the Ordinance for Its Implementation and the Concessions Act.

The subject of this material are some basic legal principles characterizing the role of public private partnership as a factor in regional development.

\section{Public - Private Partnership - basic legal characteristics.}

In Bulgarian legislation the public private partnership is characterized ${ }^{2}$ as a long-term contractual cooperation between one or more public partners, on the one hand, and one or more private partners, on the other, to carry out activities of public interest in achieving better value for the public finances invested and in spreading the risks between the partners, which is realized under the terms and conditions of the current legislation.

What legal description does the Bulgarian legislator give of the term ,activity of public interest", an activity carried out in the process of public-private partnership? The answer to this question is contained in Article 4, Paragraph 1 of the quoted Law on Public Private Partnership. Within the meaning of this particular Article an

\footnotetext{
${ }^{1}$ Practical handbook, methodology and sample standard contracts for the implementation of public private partnerships by local authorities(p.3), by order of the Council for decentralization of the state government at the Council of Ministers, Sofia, 2009

${ }^{2}$ Article 3.(1) Law on Public Private Partnership
}

activity $^{3}$ of public interest is the provision of one or more services of public interest through the funding and construction and/or management and/or maintenance of:

A/ sites of the technical infrastructure and the green system:

a) in urban areas: parking lots,garages, sites of public transport, surveillance and security systems, systems for street lighting, green spaces, parks and gardens;

b) parking lots, garages, parks and gardens in individual plots outside urban areas;

$\mathrm{B} /$ sites of the social infrastructure intended for:

a) health care;

b) education;

c) culture;

d) sports, recreation and tourism

e) social assistance, social housing and hostels;

f) serving sentences of imprisonment;

g) carrying out administrative activities by the public partners.

In Paragraph 2 of Article 4, the legislator has made a further clarification of the legal characteristics of the service of public interest, namely: a service of public interest is each service in favour of society, the responsibility for he provision of which is usually carried either under a legislative act or usually by the public partner.

What types may the listed $\operatorname{sites}^{4}$ be and to whom may they belong?

First, the sites may include:

- Land;

- Buildings;

- Facilities; movable property;

-Rights of industrial and intellectual property.

Secondly, these sites may belong to:

- The state, municipality or public law organization and/or

- The private partner.

- Which legal entities have the status of public partners?

- Public partners are grouped into three groups ${ }^{5}$, namely:

A/ Ministers and heads of departments - for the state, which have as their object activities of public interest, which are state owned and / or by virtue of a statutory act are assigned to a body of the central government;

B/ Mayors of municipalities - for the municipal Public Private Partnerships, which have as their object activities of public interest, which are owned by the relevant municipality and/or by

\footnotetext{
${ }^{3}$ Article 4.(1) Law on Public Private Partnership

${ }^{4}$ Article 5 (1) Law on Public Private Partnership

${ }^{5}$ Article 13 Law on Public Private Partnership
} 
virtue of a statutory act are assigned to the local government or municipal mayors;

C/ The state and municipal public law organizations - for public interest activities that are owned by them and/or are provided to them by law, by the act of their establishing or by another act of a legal authority.

As for the private partner as a party to a Public Private Partnership, this may be ${ }^{6}$ - capital company which is an existing or a newly established one, subject to the requirements of the Law on the Public Private Partnership.

An essential point in the Law on Public Private Partnership is the contractual nature of the relationship between the partners. The duration of the contract under the Law on Public Private Partnership can be from 5 to 35 years.

The specific terms of the contracts ${ }^{7}$ for Public Private Partnership, however, are determined on the basis of:

A/ The financial and economic indicators of the draft for Public Private Partnership, including the time required by the private partner for the recovery of the funds, invested at the specified rate of return for the private partner;

B/ The technical and/or technological characteristics of the site, through which the activity of public interest is carried out and/or of the activity of public interest.

\section{State and municipal policies on public private partnerships of public interest and/or of the activity of public interest.}

The public private activity is directly related, in terms of the expected effect, to the development on the state and municipal level.

With specific events the Council of Ministers ${ }^{8}$ of the Republic of Bulgaria determines the state policy for public private partnership by:

A/ approving, amending and updating the National program for public private partnership and Operational Plan for each programming period on the proposal of the Minister of Finance; $\mathrm{B} /$ adopting decisions for opening procedures and selecting a private partner, as well as decisions for the amendment, renewal and termination of contracts for state public private partnerships;

$\mathrm{C} /$ approving the annual report of the Minister of Finance on the implementation of the National Programme for Public Private Partnership and the Operational Plan, based on the annual reports of the public partners for the fulfilment of the contracts for the state Public Private Partnerships.

\footnotetext{
${ }^{6}$ Article 14 (1) Law on Public Private Partnership

${ }^{7}$ Article 12 (3) Law on Public Private Partnership

${ }^{8}$ Article 15 (1) Law on Public Private Partnership
}

What are the legal characteristics of the national program and operational plan $^{9}$ for Public Private Partnership?

The national programme contains the general and specific objectives, the development strategy and the key priorities for the implementation of the Public Private Partnership in the country.

The operational plan is drawn up by years and includes the projects for the Public Private Partnership and the Public Private Partnership of the state public law bodies, as well as the deadlines for the implementation of projects and the necessary means for their implementation, with the form and amount of financial support specified. The terms and values, included in the Operational Plan, are estimates. A project for Public Private Partnership, which is not included in the Operational Plan, cannot be implemented. Another important legal point with the projects for Public Private Partnership is the legal regulation of payments.

The projects for public-private partnership with budgeted payments from the state budget ${ }^{10}$, for which a procedure for selecting a private partner is about to be opened, are included as an annex to the law on the state budget of the Republic of Bulgaria for the respective year.

The specific budgetary funds ${ }^{11}$, required for payments under contracts for Public Private Partnership are included in the law on the state budget of the Republic of Bulgaria for the respective year.

Which entities ${ }^{12}$ are authorized to implement the state policy on Public Private pprtnership in this country?

A/ The ministers and heads of other departments implement the state policy on Public Private Partnership in accordance with their sector expertise.

B/ The Minister of Finance implements the state policy on the effective and efficient spending of public funds in the realization of the Public Private Partnership.

How is the policy for municipal Public Private Partnerships determined?

The body that determines this policy is the municipal council. For this purpose, the

\footnotetext{
${ }^{9}$ Article 15 (2), (3) and (4) Law on Public Private Partnership

${ }^{10}$ Article 16 (1) Law on Public Private Partnership

${ }^{11}$ Article 16 (2) Law on Public Private Partnership

${ }^{12}$ Article 17 (1) and (2) Law on Public Private

Partnership
} 
municipal council approves a municipal development plan. This is done on the basis of specific legal texts of the Regulation ${ }^{13}$ for Implementing the Law on Public Private Partnerships

According to the text of Art. 5 of this Ordinance, in the municipal development plan, prepared pursuant to Art. 9, item 7 of the Law on Regional Development, the policy is laid down for the implementation of municipal Public Private Partnerships and Public Private Partnerships for municipal public law organizations for the corresponding period of operation.

Within the meaning of Art. 20 of the Ordinance under consideration, proposals for the inclusion of public private partnership projects as an annex to the state, respectively to the municipal budget, are presented in the budgetary procedure for the corresponding year.

This plan is implemented by the Mayor of the municipality, as well as with respect to the municipal public legal organizations.

Furthermore, the municipal council ${ }^{14}$ adopts decisions for opening procedures and for choosing a private partner, as well as decisions for the amendment, renewal and termination of contracts for municipal Public Private Partnerships.

Decisions are taken by a majority of $2 / 3$ of the total number of councilors. The municipal council may adopt decisions for opening a procedure for choosing a private partner within 39 months of its election.

The program for the implementation of the municipal development plan includes in a separate section the municipal Public Private Partnerships, the deadlines for their implementation by stages and the form and amount of financial aid for each project.

The program also includes the projects for Public Private Partnerships of the municipal public law organizations. No project for Public Private Partnership can be implemented if it is not included in the program for implementation of the municipal development plan.

The municipal councils approve the annual reports of the mayors of the respective municipalities, as well as of the governing bodies

\footnotetext{
${ }^{13}$ Regulation for the enforcement of the Law on Public Private Partnership, effective from 01.1.2013 and adopted by a decree of the Council of Ministers 6 of 10.01.2013, prom. In SG, Issue 5 of January 18, 2013

${ }^{14}$ Article 18 (2), (3), (4), (5), Regulations for the enforcement of the Law on Public Private Partnership
}

of the municipal public law organizations for the fulfilment of the contracts for Public Private Partnerships by 31th of March of the following year.

An important legislative detail in the Public Private Partnership, associated with its funding, is the limiting of the annual aggregate amount of the payments ${ }^{15}$ to the private partners.

When the source of financial support are own revenues, general equalizing subsidy and/or municipal debt within the meaning of the Municipal Debt Act, the annual aggregate amount of payments to the private partners under contracts for Public Private Partnerships in each year may not exceed 15 percent of the amount of the general equalizing subsidy and own revenues, averaged for the last three years, according to the annual reports on the cash fulfilment of the municipal budget. When the source of financial support is a municipal debt within the meaning of the Municipal Debt Act, the provisions of the Law on Municipal Debt are applied.

The conclusion and fulfilment of the comtract for Public Private Partnership cannot violate the indicators and limitations, defined in the Public Finance Act and the Law on Municipal Debt for each year of the fulfilment of the contract.

What is the legal norm when a municipal project for Public Private Partnership has as its object the provision of a public interest service as the delegated state activity?

In the implementation ${ }^{16}$ of municipal projects for a Public Private Partnership which has as its object the provision of a public interest service in the public interest as an activity, delegated by the state, a condition for the acceptance of the decision for opening a procedure to select a private partner is also the favorable opinion of the competent state authority in the area of the acivity, assigned by the state.

The coordination with the competent state authority is carried out in the course of the budgetary procedure in the order, applicable to it.

For the projects the financial support from the general subsid within the funds approved by the Law on the $y$ for activities, delegated by the state delegated activities is State Budget of the Republic of Bulgaria for the relevant year, based on the uniform spending standard for the financing of the specific activity.

\footnotetext{
${ }^{15}$ Article 19 (1) and (2) Law on Public Private

Partnership

${ }^{16}$ Article 20 (1), (2), (3), (4) Law on Public Private

Partnership
} 
The annual amount of payments from the municipal budget for municipal Public Private Partnerships and Public Private Partnerships of municipal public law organizations is within the legal limits.

When for the projects for Public Private Partnerships are budgeted payments from the municipal budget ${ }^{17}$, which are also subject to the opening of a procedure for the selection of a Private Partner, these projects are included as an annex to the municipal budget of the municipality for the relevant year.

The specific budgetary appropriations needed for payments on concluded contracts for Public Private Partnerships are included in the municipal budget for the relevant year.

Through the decision to adopt the municipal budget for the relevant year, the municipal council determines:

A/ the maximum amount of payments that the municipality can take on as an obligation under new projects for Public Private Partnerships in the year, included in the program for implementation of the municipal development plan, according to the requirements of the law;

$\mathrm{B} /$ the amount of payments on the projects at the end of the budget year, including residual amount of obligations under contracts for Public Private Partnerships and the intentions of the municipality for Public Private Partnership projects during the relevant year;

$\mathrm{C} /$ the aggregate amount of payments from the municipal budget to the private partners for the relevant year on all contracts for Public Private Partnerships

What are the legal basis and the legal regulations for the conditions for including projects for Public Private Partnerships in the operational plan and the program for implementation of the municipal plan for development?

This is the Ordinance ${ }^{18}$ on the conditions and procedures for the planning and criteria for inclusion of projects for public private partnership in the Operational Plan and the program for implementation of the municipal development plan.

The supporting points in this ordinance are:

A/ The legal characteristics of the operational plan:

\footnotetext{
${ }^{17}$ Article 21 (1), (2), (3) Law on Public Private Partnership

${ }^{18}$ Ordinance on the conditions and procedures for the planning and criteria for inclusion of projects for PPP in the Operational plan...effective frm 01.1.2013
}

The operational plan is drawn up in accordance with the objectives and priorities of the National Programme for Public Private Partnerships, for each programming period by years and it contains the projects for state Public Private Partnerships and for Public Private Partnerships of state public law organizations, time schedules and the necessary means for their preparation and implementation in specified form, size and schedule for granting financial support for the whole term of the projects for public private Partnerships.

The operational plan is approved by the Council of Ministers on the proposal of the Minister of Finance within six months before the initial date of the relevant programming period.

The operational plan may be amended and / or updated within the budgetary procedure for the relevant year.

$\mathrm{B} /$ The legal characteristics of the program for the implementation of the Municipal Development Plan:

In the program for the implementation of the municipal development plan, drawn up pursuant to Art. 13 Para. 2 Pt. 7 of the Law on Regional Development, in a separate section are included the municipal Public Private Partnerships, the deadlines for their implementation by stages, as well as the form and amount of financial support for each project.

The program also includes the projects for Public Private Partnerships of the municipal public legal organizations.

The program for the implementation of the municipal development plan in its part for Public Private Partnership projects may be amended and/or updated by a decision of the municipal council.

$\mathrm{C} /$ Criteria for the inclusion of projects for Public Private Partnerships

When the PPP projects are included in the operational plan and program for implementation of the municipal development plan, the following criteria are applied:

a/ commitment to the National Programme for Public Private Partnerships, respectively the municipal development plan;

$\mathrm{b} /$ socio-economic benefits of the implementation of the project;

c/ better value for the public finances invested; $\mathrm{d} /$ size and form of the financial support, amount of the costs for preparatory activities and tolerance for the budget;

e/ degree of readiness for the implementation of the project 
The importance of each one of the criteria is determined for each programming period as part of the National Programme for Public Private Partnerships, the municipal development plan respectively.

\section{Public Register of the Public Private Partnerships.}

Within the meaning of Article 24, Paragraph 1 of the Act on Public Private Partnership the Ministry of Finance keeps and maintains a public register of the Public Private Partnerships, to which there is free access via the Internet.

What requisites ${ }^{19}$ does this register contain?

The Register of Public Private Partnerships includes:

A/ the national program for public private partnership and the Operational Plan for each programming period;

B/ the municipal projects for public private partnerships and the projects for public private partnerships of municipal public law organizations, included in the programs for the implementation of municipal development plans; $\mathrm{C} /$ decisions to open procedures for selecting a private partner;

$\mathrm{D} /$ notices for the carrying out of a procedure for selecting a private partner;

E/ decisions to open procedures to select the private partner;

F/ notices conducting a procedure for selecting the private partner;

G/ decisions for selecting a private partner;

$\mathrm{H} /$ financial and economic analysis;

I/ contracts for Public Private Partnerships without the data which are a trade or technical secret;

$\mathrm{J} /$ the report of the Minister of Finance on the implementation of a national PPP program and operational plan and the annual reports of the public partners for the fulfilment of the contracts for Public Private Partnerships;

$\mathrm{K} /$ information on the fulfilment of contracts for Public Private Partnership of the public law organizations;

$\mathrm{L} /$ the additional agreements for amendments or supplements to the contracts for Public Private Partnerships;

$\mathrm{M} /$ the contracts for the continuation of contracts for Public Private Partnerships with a successor; $\mathrm{N} /$ the decisions to terminate the contracts for Public Private Partnerships;

$\mathrm{O} /$ any other information specified by the regulations for enforcing the law;

\section{CONCLUSION}

Public Private Partnership can be qualified not only as a factor but also as an important and effective mechanism in Regional development. This mechanism can find broad scope for application as both the European and already the Bulgarian practice show..

The question is important whether this mechanism is used to the full by the Bulgarian municipalities.

The recommendations ${ }^{20}$ in this regard are aimed at the implementation of a Public Private Partnership in the following areas;

a) Production of electricity and heat;

b) Water supply and waste water discharge including water purification;

c) Waste collection, transportation, disposal and recycling;

d) Social activities and management of social infrastructure;

(Hospitals, schools, cultural and sports centers)

e) Town development services (including street lighting), green areas and parks;

f) Postal, telecommunications and information services;

g) Services for the security of the populationfire-fighting and police activities,prisons, etc.

\section{REFERENCES}

1. Law on Public Private Partnership - Effective 01/01/2013, promulgated in the State Gazette(SG), Issue 45 of 15 June 2012. amend. SG. Issue.87 of November 9, 2012. suppl. SG. Issue.102 of December 21, 2012. amend. SG. Issue. 15 of February 15, 2013 .;

2. Ordinance on the conditions and procedures for planning and criteria for inclusion of projects for public private partnership in the operational plan and program for the implementation of the Municipal Development Plan - Approved by Decree № 6 of 10.01.2014, amended. SG Issue 5 of 18.01.2013, effective from 01.01.2013.;

3. Regulations for the implementation of the Law on Public Private Partnership - With effect from 01.01.2013 and adopted by Decree № 6 of 01.10 .2013 , promulgated in the. SG 5 of January 18, 2013 .;

4. Practical handbook, methodology and sample standard contracts for the implementation of public private partnerships by local authorities - by order of the council for decentralization of the state government at the Council of Ministers Sofia, 2009 ;;

5. www.minfin.bg - Ministry of Finance;

6. Lex.bg - Legal Portal.

\footnotetext{
${ }^{19}$ Article 24 (2) Law on Public Private Partnership contracts........,p. 8

${ }^{20}$ Practical handbook, methodology and sample standa 
VELKOVSKA G.

Trakia Journal of Sciences, Vol. 13, Suppl. 1, 2015 